\title{
PRECEDE-PROCEED Theory Regarding Socio-Cultural Aspects that Influence the Treatment of Healthy Reproduction Organs among Senior High School Female Students in Surakarta
}

\author{
Santy Irene Putri'), RB Soemanto²), Yulia Lanti Retno Dewi 3) \\ 1) Masters Program in Public Heath, Sebelas Maret University, Surakarta \\ 2) Faculty of Social and Political Sciences, Sebelas Maret University, Surakarta \\ 3) Faculty of Medicine, Sebelas Maret University, Surakarta
}

\begin{abstract}
Background: The group that has been vulnerable to the abandonment of reproductive health rights in Indonesia is adolescents. The lack of adolescents' awareness toward their behaviors in maintaining genital organs cleanliness is due to socio-cultural limitations might cause negative impact toward their reproductive health. This study aimed at analyzing the socio-cultural aspects that influenced the behaviors in treating healthy reproductive organs among female senior high school students in the City of Surakarta.

Subjects and Method: This was a mixed-method study with quantitative and qualitative approach. This study was conducted in State Senior High School 1, Al-Islam 1 Senior High School and Regina Pacis Senior High School; all of these senior high schools were located in the City of Surakarta, from February to March 2017. A total of 120 subjects were selected by stratified random sampling. In addition, the sample also included 5 mothers and fathers who had been selected by purposive sampling. The dependent variable was the behaviors in treating reproductive organs. The independent variables were knowledge toward reproduction organ health, family support, toilet/ bathroom availability, clean water availability, culture and information exposure. The dependent and independent variables were collected by a set of questionnaire and analyzed by path analysis. The qualitative data were collected by in-depth interview and analyzed by Miles Huberman method.

Results: The behaviors in treating reproductive organ were influenced by good knowledge $(\mathrm{b}=$ $0.21 ; \mathrm{SE}=0.09 ; \mathrm{p}=0.020)$, high information exposure $(\mathrm{b}=0.20 ; \mathrm{SE}=0.07 ; \mathrm{p}=0.005)$, positive culture $(b=0.15 ; \mathrm{SE}=0.07 ; \mathrm{p}=0.039)$, toilet/ bathroom availability $(b=0.21 ; \mathrm{SE}=0.07 ; \mathrm{p}=0.026)$, clean water availability $(b=0.14 ; \mathrm{SE}=0.08 ; \mathrm{p}=0.073)$ and strong family support $(\mathrm{b}=0.16 ; \mathrm{SE}=$ $0.08 ; \mathrm{p}=0.041$ ). Then, the knowledge of reproductive health was influenced by high information exposure $(b=0.31 ; \mathrm{SE}=0.07 ; \mathrm{p}<0.001)$ and positive culture $(b=0.16 ; \mathrm{SE}=0.07 ; \mathrm{p}=0.016)$.

Conclusions: The behaviors in treating reproductive organs are influenced by good knowledge, high information exposure, positive culture, toilet availability, clean water availability and strong family support. The knowledge of reproductive health are influenced by high information exposure and positive culture.
\end{abstract}

Keyword: precede-proceed, path analysis, socio-culture, reproductive health

\section{Correspondence:}

Santy Irene Putri. Masters Program in Public Heath, Sebelas Maret University, Surakarta. Email: santyireneputri@yahoo.co.id. Mobile: +6285785836884.

\footnotetext{
BACKGROUND

Reproductive organs are the body parts among female adolescents that have a vital function within offspring continuation process. Each part has important functions, shows the aspects of sexuality and shapes e-ISSN: 2549-1172 (online)
}

as well as serves as secondary sexual peculiar characteristics (Pinem, 2009). Reproductive health should not only be free of disease, system-defect, function-defect and reproductive process-defect but also be 
Journal of Health Promotion and Behavior (2017), 2(1): 27-40

https://doi.org/10.26911/thejhpb.2017.02.01.03

health physically, mentally and socially (Kemenkes RI, 2015).

Reproductive organs treatment is a part of very important activity. Reproductive organs that have not been treated appropriately might cause various negative impacts such as infection (Kusmiran, 2012). Entering the adolescence, physical and sexual development starts progressing rapidly. Adolescents who soon will continue their offspring and become parents should have good reproductive health so that they might bear healthy generation.

The problems of adolescents' reproductive health globally nowadays are sexual crime and reproduction. The treatment of reproductive health is a relatively new concept; however, this concept generally becomes a very important component in health. Reproductive health service is necessary along the life of each individual, especially for women, and along adolescence(Devi, 2013). Dasgupta and Sarkar (2008) in Ozyazicioglu (2012) stated that the lack of adolescents' awareness toward genitalia cleanliness and, through scientific evidence, that is due to socio-cultural limitations might provide negative impacts toward the adolescents' health.

Adolescence is a period of puberty change, sexual maturation, curiosity and experiment that causes these adolescents to be vulnerable toward infection. Discussions regarding sexual-related matters are taboo. Doubtful knowledge that comes from unreliable sources causes adolescents to explore themselves in any matters that might cause teen pregnancy, unsafe abortion, being exposed to sexually transmitted infections and HIV/AIDS infection. Furthermore, such matters will inhibit the social and economic development of this nation. In relation to these situations, improving adolescents' knowledge and changing their attitudes might strengthen the well-qualified practice 28 in behaviors of reproductive organ treatment.

Two figures who analyzed human behaviors from the health aspects were Green and Kreuter in their PRECEDE-PROCEDE behavioral theory. PRECEDE, as an alternative, is started from needs assessment, needs classification in the social level and classification toward which health problem might contribute to social needs. Through these stages, people might determine the behavioral and the social problems that are related to the health problems. Meanwhile, PROCEED is an ecological diagnosis that impliesorganizationalpolicy, regulation and construct in environmental education and development (Terry, 2015).

Lawrence Green (1980) also explained thatbehaviors are determined or are shaped by predisposition factors (or internal factors within individuals and these factors include knowledge, attitude, belief and adopted norms and values), supporting factors (health facilities, access to health facilities, health regulation and health-related skills) and strengthening factors (factors that might inhibit behavioral changes) (Sulaeman, 2014).

The group that has been vulnerable to the abandonment of reproductive health rights in Indonesia is adolescents. Adolescents are silent victims who have been judged unfairly, whereas adolescence is the age when reproductive organs are vulnerable to reproductive organ infections, pregnancy and drug use (Efendi, 2009). Globally, adolescents who give birth early age (ABR) in 2015 have been 44 individuals per 1,000 female adolescents in the age range of 15-19 years old (WHO, 2016).

Data on the incidence of reproductive organ infection provided by Dinas Kesehatan Provinsi Jawa Tengah in Anggraeni (2014) state that in 2011 there were 10,752 cases of reproductive organ infection (due e-ISSN: 2549-1172 (online) 
to fungi bacteria, parasites and trichomonas virus, vagina bacteria and gonorrhea), while in 2012 this number decreased into 8,671 cases. The rate of reproductive organ infection used to decrease. However, the cases occurred in community might not be detected in overall. Therefore, the objective of the study was analyzing the socio-cultural aspects that influenced the behaviors in treating healthy reproductive organs among senior high school female adolescents in the City of Surakarta.

$\frac{\text { SUBJECTS AND METHOD }}{\text { Research Design }}$

This study implemented mixed methods, namely a method that focused toward two quantitative and qualitative approaches. The design of this study was analytic observational by using cross-sectional design. In this study, the qualitative data were complimentary to the quantitative data. The qualitative data analysis was conducted after the quantitative data analysis had been done. The design that the researchers implemented in the qualitative study was case study. The study was conducted in public and private senior high schools that represented the favorite senior high schools in the City of Surakartya, namely State Senior High School 1, Al-Islam 1 Senior High School and Regina Pacis-Ursulin Senior High School. This study was conducted from February to March 2017.

\section{Population and Sample}

The population in this study was the female students from all public and private senior high schools in the City of Surakarta. The samples in the quantitative study were 120 subjects, while the samples in the qualitative study were 5 subjects (fathers and mothers). The sampling technique that the researchers implemented in the quantitative study was stratified random sampling. The samples for the quantitative study who e-ISSN: 2549-1172 (online) had been gathered from the three senior high schools were 40 subjects and they were selected from Grade $\mathrm{X}$ of Natural Science, Social Science and Language Program. On the other hand, the sampling technique that the researchers implemented in the qualitative study was purposive sampling.

\section{Research Variables}

There were seven variables in this study that consisted of dependent and independent variables. The dependent variable was behaviors in treating reproductive organs, while the independent variables were knowledge, culture, clean water availability, toilet/ bathroom availability, family support and information exposure.

\section{Operational Definition}

The operational definition of culture variable was the trust/ habit and tradition that hadbeen performedby the subjects, whether the good one or the bad one, regarding the behaviors in treating reproductive organs. Then, the operational definition of reproductive health knowledge was the subjects' capacity to respond appropriately to the questions related to the intended reproductive health and these questions included: definition of reproductive health, treatment of reproductive organs and menstruation and its treatment. Next, the operational definition of clean water availability was the access to clean water and the condition of the water used by the subjects. Last but not the least, the operational definition of toilet/ bathroom availability was the possession and the cleanliness of facilities that the subjects had been using for taking bath and defecating.

Family support was positive social support/ interaction or the useful behaviors that had been performed by parents/ siblings and other family members in any activities related to the reproductive organs treatment. The forms of this support might 
Journal of Health Promotion and Behavior (2017), 2(1): 27-40

https://doi.org/10.26911/thejhpb.2017.02.01.03

be informational, instructional, emotional, instrumental and advocacy-related.

Information exposure was the type of mass media and information source and the subjects' frequency in viewing or reading information related to the treatment of reproductiveorgansthrough audio and visual media; information exposure included friends, family, medical staffs (doctors, nurses, midwives or expert medical staffs who understood reproductive health), print media and electronic media. Behaviors in the treatment of reproductive organs, on the other hand, were the subjects' actions in maintaining the cleanliness of their reproductive organs and these behaviors included the use of treatment product and the manners of cleansing female intimate organs.

\section{Data Analysis}

In gathering the quantitative data, the researchers distributed questionnaires, while in gathering the qualitative data the researchers performed in-depth interview. The variable that had been measured in the study was family support, which included informational, instructional, emotional, ins- trumental and advocacy-related support. In performing the quantitative data analysis, the researchers performed path analysis. According to Murti (2015) the steps in performing data analysis using path analysis are as follows: model specification, model identification, conformity model, parameter estimation, and respesification model. On the contrary, in performing the qualitative data analysis the researchers performed Miles and Huberman interactive model. There are four steps in the interactive model analysis technique according to Miles and Huberman, namely data collection, data reduction, data presentation, conclusions, and data verification.

\section{Reliability}

Based on the results of total-item correlation reliability test the researchers found that culture, clean water availability, toilet/ bathroom availability, family support, information exposure and behaviors in the treatment of reproductive organs had $\mathrm{r}$ count $\geq$ 0.20 and Cronbach's Alpha $\geq 0.70$; as a result, all items were declared reliable. Table 1 shows the results of reliability test.

Table 1. Results of reliability test

\begin{tabular}{lcc}
\hline \multicolumn{1}{c}{ Variable } & $\begin{array}{c}\text { Item Total } \\
\text { Correlation (r) }\end{array}$ & $\begin{array}{c}\text { Cronbach's } \\
\text { Alpha }\end{array}$ \\
\hline Reproductive health knowledge & $\geq 0.26$ & 0.75 \\
Information exposure & $\geq 0.30$ & 0.73 \\
Family support & $\geq 0.47$ & 0.89 \\
Toilet/bathroom availability & $\geq 0.42$ & 0.80 \\
Clean water availability & $\geq 0.21$ & 0.77 \\
Culture of using female intimate organs cleansing & $\geq 0.22$ & 0.73 \\
materials & $\geq 0.20$ & 0.74 \\
Behaviors in the treatment of reproductive organs & & \\
\hline
\end{tabular}

\section{RESULTS}

The dimensions of characteristics from the three senior high schools are viewed in terms of age, religion, tribe, mother's educational background and mother's occupation. Table 2 showed that from 120 subjects the researcher found that 50.80\% of the subjects were 15 years old and $45.80 \%$ of the subjects were 16 years old because the subjects were $\mathrm{X}$ grade students; $65.00 \%$ of the subjects were Moslem; 75.00\% of the subjects were Javanese with the location of sample gathering activities in the City of Surakarta; $53.30 \%$ of the subjects' mother's education were undergraduate; and $47.50 \%$ 
of the subjects' mothers did not have any occupation.

Table 2. Subjects' characteristics

\begin{tabular}{llcc}
\hline \multicolumn{1}{c}{ Characteristics } & \multicolumn{1}{c}{ Criteria } & n & \% \\
\hline Age & 14 years old & 4 & 3.4 \\
& 15 years old & 61 & 50.8 \\
Religion & 16 years old & 55 & 45.8 \\
& Islam & 78 & 65.0 \\
\multirow{4}{*}{ Tribe } & Christian & 19 & 15.8 \\
& Catholic & 23 & 19.2 \\
\multirow{3}{*}{ Mother's Educational Background } & Javanese & 90 & 75.0 \\
& Chinese & 23 & 19.2 \\
& Mixed & 7 & 5.8 \\
& Elementary School & 2 & 1.7 \\
& Junior High School & 2 & 1.7 \\
& Senior High School & 27 & 22.5 \\
& Diploma & 21 & 17.5 \\
Mother's Occupation & Undergraduate & 64 & 53.3 \\
& Graduate & 4 & 3.3 \\
& None & 57 & 47.5 \\
& Civil Servant & 29 & 24.2 \\
& Private Company/ Institution & 10 & 8.3 \\
& Employee & & \\
& Entrepreneur & 24 & 20.0 \\
\hline
\end{tabular}

The descriptive statistic results of continuous data in the form of culture, clean water availability, toilet/ bathroom availability, fa- mily support, information exposure, knowledge and behaviors in the treatment of reproductive organs shows in Table 3 .

Table 3. Univariate analysis for the variables

\begin{tabular}{lccccc}
\hline \multicolumn{1}{c}{ Variables } & n & Min & Max & Mean & SD \\
\hline Good knowledge & 120 & 32 & 48 & 38.50 & 3.36 \\
High information exposure & 120 & 21 & 38 & 28.50 & 4.26 \\
Strong family support & 120 & 33 & 50 & 39.53 & 3.65 \\
Toilet/bathroom availability & 120 & 19 & 34 & 25.67 & 3.06 \\
Clean water availability & 120 & 15 & 35 & 27.30 & 3.72 \\
Positive culture & 120 & 30 & 53 & 38.99 & 4.14 \\
Behaviors in the treatment of reproductive organs & 120 & 31 & 48 & 38.77 & 3.72 \\
\hline
\end{tabular}

Table 3 showed that each variable has relatively small data variation. Mean of the above table described the average score, while standard deviation (SD) of the above table described how far the data variation. The small SD score indicated that the data had been representative.

Table 4. Bivariate analysis for the influence of reproductive health knowledge, family support, toilet/ bathroom availability, clean water availability, culture and information exposure toward behaviors in the treatment of reproductive organs

Good knowledge Independent Variables

Strong family support

Toilet/bathroom availability

Clean water availability

Positive culture

High information exposure

$\mathbf{r} \quad \mathbf{p}$

$0.42<0.001$

0.28

0.002

0.36

$<0.001$

0.24

0.009

0.39

$<0.001$

0.42

$<0.001$ 
Journal of Health Promotion and Behavior (2017), 2(1): 27-40

https://doi.org/10.26911/thejhpb.2017.02.01.03

Table 4 showed that good knowledge $(r=$ $0.42, \mathrm{p}<0.001$ ), strong family support $(\mathrm{r}=$ $0.28, \mathrm{p}=0.002$ ), toilet/bathroom availability $(\mathrm{r}=0.36, \mathrm{p}<0.001)$, clean water availability $(\mathrm{r}=0.24, \mathrm{p}=0.009)$, positive culture $(\mathrm{r}=$
0.39, $\mathrm{p}<0.001)$ and high information exposure $(\mathrm{r}=0.42, \mathrm{p}<0.001)$ had positive and statistically significant influence toward behaviors in the treatment of reproductive organs.

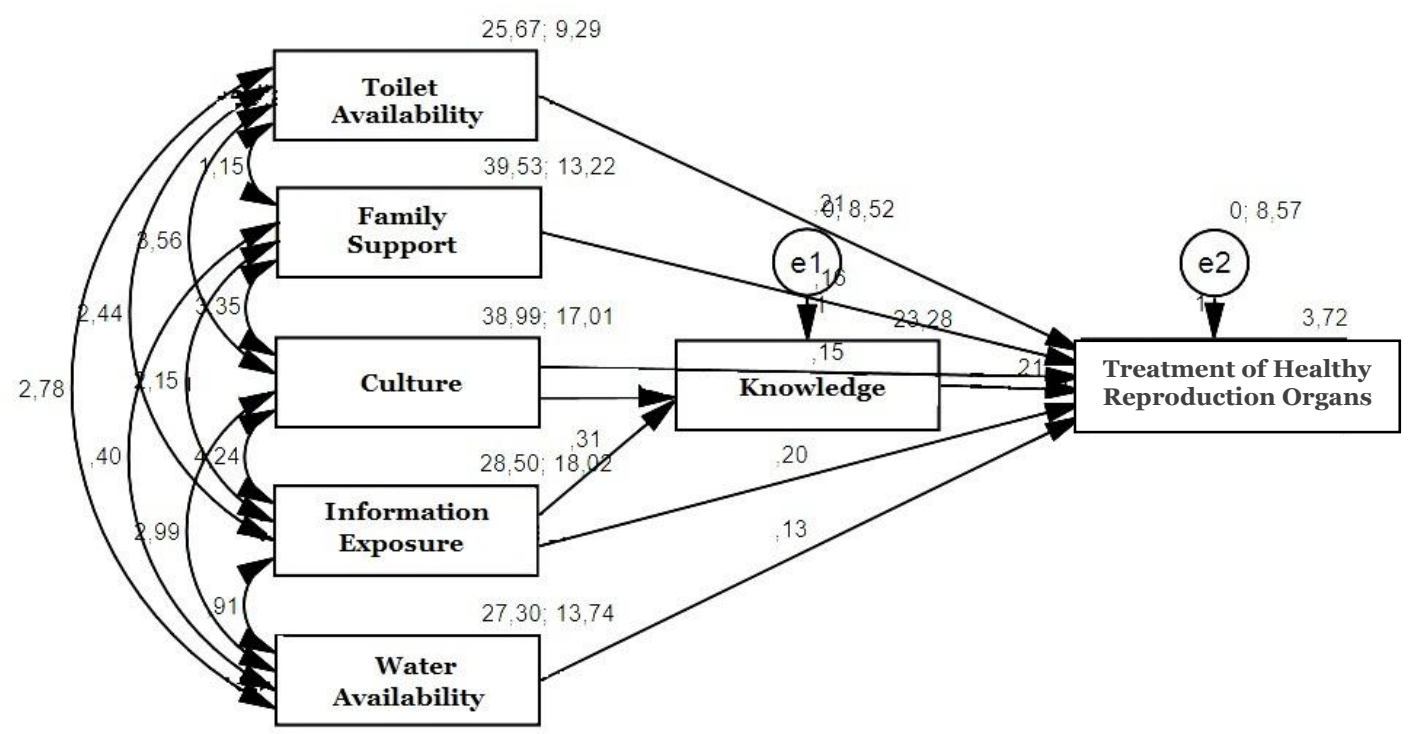

Picture 1. Structural model of path analysis

Picture 1 showed the structural model after having been estimated by IBM SPSS AMOS 20; as a result, the researchers attained the above results. The indicators that showed the fitness of the path analysis model in Table 5 also showed goodness of fit measure; from the goodness of fit measure,

\begin{tabular}{|c|c|c|c|c|c|c|}
\hline \multicolumn{2}{|c|}{$\begin{array}{l}\text { Dependent } \\
\text { Variables }\end{array}$} & Independent Variables & $\mathbf{b}^{*}$ & $\mathbf{S E}$ & $\mathbf{p}$ & $\boldsymbol{\beta}^{* *}$ \\
\hline \multicolumn{7}{|c|}{ Direct Influence } \\
\hline Behaviors & $5 \longleftarrow$ & Good knowledge & 0.21 & 0.09 & 0.020 & 0.19 \\
\hline Behaviors & $S \longleftarrow$ & High information exposure & 0.20 & 0.07 & 0.005 & 0.23 \\
\hline Behaviors & $s \longleftarrow$ & Positive culture & 0.15 & 0.07 & 0.039 & 0.17 \\
\hline Behaviors & $\longleftarrow$ & Toilet/bathroom availability & 0.21 & 0.10 & 0.026 & 0.17 \\
\hline Behaviors & $\longleftarrow$ & Clean water availability & 0.14 & 0.08 & 0.073 & 0.14 \\
\hline \multirow{2}{*}{\multicolumn{2}{|c|}{$\begin{array}{l}\text { Behaviors } \longleftarrow \longleftarrow \\
\text { Indirect Influence }\end{array}$}} & Strong family support & 0.16 & 0.08 & 0.041 & 0.15 \\
\hline & & & & & & \\
\hline \multicolumn{2}{|l|}{ Knowledge } & High information exposure & 0.31 & 0.07 & $<0.001$ & 0.40 \\
\hline \multirow{2}{*}{\multicolumn{2}{|c|}{$\begin{array}{l}\text { Knowledge } \\
\text { Model Fit }\end{array}$}} & Positive culture & 0.16 & 0.07 & 0.016 & 0.20 \\
\hline & & & & & & \\
\hline \multicolumn{2}{|c|}{$\mathrm{CMIN}=2.57$} & $\mathrm{p}=0.463(>0.050)$ & & & & \\
\hline \multicolumn{2}{|r|}{$=0.98$} & $(\geq 0.90)$ & & & & \\
\hline \multirow{2}{*}{\multicolumn{2}{|c|}{$\begin{array}{ll}\mathrm{CFI} & =1.00 \\
\text { RMSEA } & =0.00\end{array}$}} & $(\geq 0.95)$ & & & & \\
\hline & & $(\leq 0.08)$ & & & & \\
\hline
\end{tabular}

the researchers attained CMIN fit index that had been equal to 2.57 with $\mathrm{p}=0.463>0.050$; $\mathrm{NFI}=0.98 \geq 0.90$; CFI $1.00 \geq 0.95$; RMSEA= $0.00 \leq 0.08$. In other words, the empirical model met the criteria that had been defined and been stated by the empirical data. 
From Table 5 it is apparent that behaviors in the treatment of reproductive organs had been influenced directly by good knowledge, high information exposure, positive culture, toilet/ bathroom availability, clean water availability and strong family support.

Every one unit increase on good knowledge would improve behaviors in the treatment of reproductive organs approximately 0.21 unit $(b=0.21 ; \mathrm{SE}=0.09 ; \mathrm{p}=0.020)$.

Every one unit increase on high information exposure would improve behaviors in the treatment of reproductive organs approximately 0.20 unit $(b=0.20 ; \mathrm{SE}=0.07$; $\mathrm{p}=0.005$ ).

Every one unit increase on positive culture would improve behaviors in the treatment of reproductive organs approximately 0.15 unit $(b=0.15 ; \mathrm{SE}=0.07 ; \mathrm{p}=0.039)$.

Every one unit increase on toilet/ bathroom availability would improve behaviors in the treatment of reproductive organs approximately 0.21 unit $(b=0.21 ; \mathrm{SE}=0.10$; $\mathrm{p}=0.026$ ).

Every one unit increase on clean water availability would improve behaviors in the treatment of reproductive organs approximately 0.14 unit $(b=0.14 ; \mathrm{SE}=0.08 ; \mathrm{p}=$ 0.073).

Every one unit increase on strong family support would improve behaviors in the treatment of reproductive organs approximately 0.16 unit $(b=0.16 ; \mathrm{SE}=0.08 ; \mathrm{p}=$ 0.041).

Knowledge was influenced by high information exposure and positive culture. Every one unit increase on high information exposure would improve reproductive health knowledge approximately 0.31 unit $(b=0.31$; $\mathrm{SE}=0.07 ; \mathrm{p}<0.001$ ).

Every one unit increase on positive culture would improve behaviors on the treatment of reproductive organs approximately 0.16 unit $(b=0.16 ; \mathrm{SE}=0.07 ; \mathrm{p}=$ o.016).

e-ISSN: 2549-1172 (online)

\section{DISCUSSION}

1. Theinfluence of reproductive health knowledge toward behaviors in the treatment of healthy reproductive organs among female senior high school adolescents

There is a positive and statistically significantrelationshipbetween reproductive health knowledge and behaviors in the treatment of reproductive organs. Knowledge about the use of pads and the manner of cleansing genital area would influence the important practice of maintaining the menstruation period cleanliness. The ill-hygienic menstruation practice might influence female adolescents' health and might trigger vulnerability toward the infection of reproductive path, hip inflammation and other complications (Upashe, 2015). The selection of female organ cleansing product has been based on the availability and the community knowledge about each product (Fashemi, 2013).

Poor knowledge and bad behaviors regarding personal cleanliness have negative consequence. Statistically, knowledgehas significant relationship to cleanliness-maintaining behaviors. Knowledge and awareness are actions that have causal relationship to behaviors. According to Aseffa (2014) who measured students' knowledge and their proportion in performing maintaining-cleanliness behaviors, there is quite high positive relationship among school children who had sufficient knowledge. The results of logistic regression analysis showed that differences in maintaining-cleanliness behaviors had statistically significant relationship to the status of students' knowledge regarding water-handling problems. Thereby, knowledge is an important factor in influencing maintainingcleanliness behaviors positively. Correct information regarding the practice of menstruation is a very important matter (Upashe, 2015). 
Limited knowledge might also cause illhygienic practice such as reusing the same cloth over and over without appropriately washing it, abandoning health problems and alike. Female adolescents often deal with problems and limited knowledge regarding menstruation and such situation usually is not handled appropriately. Appropriate knowledge will help them to train the right practice of safe and hygienic menstruation and, as a result, they will be able to escape from traditional belief, misunderstanding and limitation toward menstruation (Thakur, 2014).

2. The influence of family support toward behaviors in the treatment of healthy reproductive organs among senior high school female adolescents

There is a positive and statistically significant relationship between family support and behaviors in the treatment of reproductive organs. It is important that all female adolescents within their family should be educated and be informed about the importance of using pads. The introduction of pads is very necessary and its influence will be apparent in the long term.

Family support is important for performing positive behaviors. Supporting the mastery of adolescent's behaviors is very important in order to promote healthy behaviors while preventing the behaviors that might risk their health and this individual factor is perhaps very important for adolescents. For female adolescents, increasing support seems directly prevent the behaviors that might risk their health. According to Kwon (2014), support indirectly influences the behaviors that might risk female adolescents' behaviors through disobedience. Furthermore, support also indirectly influence health-promoting behaviors through mastery, which supports different developmental path for adolescents' health risks.

Based on the results of in-depth interview, most of the parents provided positive supports to behaviors in the treatment of their daughters' reproductive organs. The statement of their support might be noticed through the following quotations:

"Yes, I provide suggestions according to what I have learned. Usually I also pay attention to the TV programs, the ones that discuss treatment of reproductive organs." (Informational support)

"Yes, I give directions so that my daughter will understand. If we just provide information without any direction, then my daughter might forget or might not pay attention to the given information. The situation will be different if we provide practical example. For instance, I teach my daughter how to cleanse her vagina: she should rub it from the front to the back. Then, when she is in a public toilet, I tell her to stand up while she is urinating since there are many bacteria around the closet.' (Instructional support)

Parental support, especially parental monitoring, parental caution and parental autonomous support, is consistently associated to various healthy behaviors in literature. Turning upbringing into a special domain describes that different support dimension might influence healthy behaviors through different mechanisms. Parental monitoring, autonomous support and warmth provided by parents might be associated to adolescents' healthy behaviors; however, the mechanisms that the parents implement might be different. Therefore, it is important to consider the three dimensions (Kwon, 2014). Based on those explanations, the results of this study are not in accordance to the previous studies because family support directly influences behaviors in the treatment of reproductive organs. 
3. The influence from toilet/bathroom availability toward behaviors in the treatment of healthy reproductive organs among senior high school female adolescents

There is a positive and statistically significant relationship between toilet/ bathroom availability and behaviors in the treatment of reproductive organs. Toilet paper is a personal health product that has been available anywhere and it is assumed that toilet paper contains chemicals. Formaldehyde does not only cause irritation but also contain canceragent. There are more than 100,000 chemicals that have been used in commercial products. Several chemicals are known to have quite enormous risk toward health (Majerovich, 2010).

A study by Garn (2014) provided important insight regarding how to improve more effective use of toilet in schools located in developing countries, which potentially led to better allocation of school sanitation resources and to improvement on the results of children's health and education. Schools are known to have water resources that have been available for cleaning the residues of urination/ defecation and to have supplies for cleaning their toilets. In addition, schools are also known to have various sanitation facilities namely traditional closets, closet ventilation, pre-fabricated plastic closet and other types of closet along with kina. On the contrary, in terms of toilet condition these closets look dirty; closet facilities look very dirty, there are urination residuals, there are not any shutters on most of the toilets, there are many flies inside the closets and there are strong odors both insider and outside the facilities.

There are several factors that play important role in the use of school toilet and these factors include students' ratio to the toilet, toilet type, toilet number and even cleanliness. Cleanliness is very important bee-ISSN: 2549-1172 (online) cause there is a possibility that this cleanliness is associated to students' excreta exposure. The limited use of toilet, the lack or the absence of health products and materials, the unclean toilet and basin are among the factors that cause the students to not use the school toilets. According to Ozcelik (2014), several students stated that they could not use the toilets when they needed them and some of these students stated that dirty toilets were the most important cause of that situation.

Most students wash their hand after they enter the toilet. On the contrary, there have not been any students who wash their hand before using the toilet. Most female children dry their genital area after they cleanse it with water and only few of them who use tissue roll. In the meantime, some other female children use cloth for cleansing their genital area with water. Most schools provide sitting toilet (Ozyazicioglu, 2011). A study by Keith (2006) showed that several schools had separate toilets for female children and these toilets were equipped with doors and locks; clean water sources were also available nearby these toilets. These toilets were equipped with soaps, a mechanism for cleaning urination/ defecation excreta, sanitation and supplies for keeping the toilet cleanliness.

4. The influence of clean water availability toward behaviors in the treatment of healthy reproductive organs among senior high school female adolescents.

There is a positive and almost statistically significant relationship between clean water availability and behaviors in the treatment of reproductive organs. The lack of clean water availability might influence the behaviors of an individual; due to this situation, the individual might decrease the use of clean water. Cultural aspect or action is associated to water, sanitation and cleanliness and this in- 
cludes the aspects that have been associated to the water source location or the sanitation facility (Campbell, 2015).

Female adolescents' discomfort in school environment during menstruation is due to the lack of privacy, the disposal of menstruation-cleansing materials or the insufficient clean water and sanitation facility in the school. Developed countries economically have sanitation facility that enable women to manage their menstruation personally because these countries have well-maintained clean water, flowing water, well-kept privacy, abundant sanitation materials and abundant underwear. These countries in the same time also have female teachers and female school nurses who support menstruation-related management. The existing evidence supports the claim that the lack of water and sanitation facility for managing menstruation in school environment causes discomfort and going to school-avoidance in during menstruation (Jasper, 2012).

When the menstruation cloth is cleaned and is used again, ideally the used cloth will be washed with soap and water. Then, the cloth will be dried under the sunlight. However, young and adult females often try to dry the cloth in a hidden room and this act might cause the cloth to not be totally dried; as a result, it might facilitate the growth of dangerous bacteria. Furthermore, many young females do not have access to soap and water especially when they want to cleanse their genital area secretly. Therefore, their cleanliness in general is poor due to the limited access to soap and water (Keith, 2006). Cloth cleansing is often done without soap or with dirty water and the drying process is often done inside a room instead of under the sunlight or in open air area due to social limitation and taboo. Such cleansing process might cause the reuse of unclean materials (Sumpter, 2013).
The improvement of water quality and quantity, the practice of sanitation and the cleanliness are potential to prevent at least 9.00\% of global disease spread. Menstruation cleanliness is one of the aspects that should be improved and, indeed, this aspect should be identified during the design of sanitation program in the level of global policy. Good menstruation management depends on clean water supply for cleansing activities and on sufficient sanitation facility. Cleansing genital area regularly with soap and water is sufficient to prevent infection. Water is available in all schools; however, if the water is far from the toilet location the female students should bring the water across the schoolyard. The number of toilets for female students is also far below the government's standards. Several female students who live nearby the school should run home to change their cloth and return to the school. On the other hand, other female students do not go to school during their menstruation period and, therefore, they suffer from academic drawbacks. In turn, the chance that these female students will be dropped out from the school becomes higher. Some other female students still go to school and they do not change their pads until the end of their school period. Therefore, water availability inside the toilet/ bathroom is very important for cleansing hands and taking bath (Parker, 2014). A study by Shanbhag (2012) reported that there were several female students who never cleansed their genital area after they had done their urination.

\section{The influence of culture toward behaviors in the treatment of healthy reproductive organs among senior high school female students}

There is a positive and statistically almost significant relationship between culture and behaviors in the treatment of reproductive organs. According to the existing theory e-ISSN: 2549-1172 (online) 
which states that the culture in maintaining reproductive organs cleanliness, in this case the practice of maintaining intra-vaginal cleanliness (IVP), which has been the term for describing multiple practices that women conduct in order to modify the condition of their vaginal environment, will influence behaviors in the treatment of reproductive organs. Intra-vaginal practice might include internal vaginal cleansing by means of liquid, dry substance insertion for absorbing vaginal liquid or for "tightening" vagina and herbal and other substance insertion for various needs such as improving sexual intercoursequality and treating leucorrhea. Intravaginal practice is also associated to unexpected and dangerous side effects. Cleansing vagina and inserting chemical products or other substances into vagina might disturb genital mucosa and vaginal lactobacillus that grows in healthy vagina. Such act results in the increasing risk for women to have poor healthn (Esber, 2016).

Glycerol, the basic material for lubricant, might damage or irritate vagina. Mucous membrane in vagina and vulva quickly absorbs chemicals without metabolizing these materials (Nicole, 2014). Piper betel L. (Piperacea) is an ethno-medicinal plant that has been used in traditional herbal recipes around several countries (Singburaudom, 2015).

Douching method and intensity, especially the pressured one, has been associated to negative impacts for health (Chatwani, 2006). Decisive factors in douching behaviors have not been understood although douching has been practice by many women (Chatwani, 2006). Pouring vagina with cleansing solution aims at cleaning the vagina, controlling the body odor or controlling the vagina elasticity. Itches and irritations are general problems throughout the world (Attieh, 2016). The practice of douching is shaped by social and cultural norms regarde-ISSN: 2549-1172 (online) ing female cleanliness in their reproductive matters (McKee, 2009).

In this study, the researchers found that culture does not have direct relationship to behaviors in the treatment of reproductive organs; instead, it has indirect relationship to the behaviors by means of knowledge. Based on a study by McKee (2009), knowledge about douching had been passed down from one generation to another, especially by mothers and female relatives when they were sexually matured. Information related to douching was provided in the context of female cleanliness practice that emphasized the importance of cleanliness.

\section{The influence of information expo- sure toward behaviors in the treat- ment of healthy reproductive organs among senior high school female ado- lescents}

There is a positive and statistically significant relationship between information exposure and behaviors in the treatment of reproductive organs. Intensive information exposure positively and significantly influences behaviors in the treatment of reproductive organs. Television and radio units have been the most general source for attaining information related to cleanliness (Saffari, 2014). Female children from families with radio and/or television units tend to have better knowledge about menstruation in comparison to those who do not have radio/television units. Information regarding menstruation and menstruation cleanness that have been attained in schools and families will influence the adolescents' cleanliness-maintaining behaviors. The level of knowledge regarding menstruation cleanliness seems to improve along with the time that has been spent for watching television programs/listening to radio stations.

Parents are the main source of health information, especially for the sensitive problems, although students still refer to their 
teachers. The development into a modern century provides an impact that mass media and Internet have become increasingly more popular as information source. When they deal with health problems, many female adolescents consult their parents. However, mass media and Internet overtake parents and teachers as the main source of health information for senior high school students. In addition to consulting their parents, female adolescents who are in their developmental period also refer to mass media, Internet and teachers in order to attain suggestions regarding behavioral and interpersonal problems. Further exploration regarding adolescent access to health information surprisingly reveals that students mainly refer to their teachers especially for the problems of reproductive organs. This new technology potentially becomes a new method that might be useful for disseminating health information as long as users are cautious with the credibility and the reliability of the information (Tsai, 2013).

New service type for adolescents, such as reliable online sources and interactive sites, should be developed in order to providepositive impacts toward adolescents' behaviors although the results of several studies show that many students accept health information from their institutions. Latest evidence shows that students become increasinglydependenton Internet asthe source of health information (Kwan, 2010).

A study by Chillos (2006) mentioned that most information has been attained from parents and schools in which conversation and provision of accurate information becomes very important point in influencing adolescents' knowledge and behaviors.

Based on the results of the study, the researchers might conclude that behaviors in the treatment of reproductive organs are influenced by good knowledge of reproductive health, high information exposure, positive culture, toilet availability, clean water availability and strong family support. Meanwhile, knowledge of reproductive health is influenced by high information exposure and positive culture.

\begin{tabular}{l}
\hline REFERENCE \\
\hline Anggraeni NN, Damayanti FN (2014). Hu- \\
bungan Pengetahuan dengan Sikap \\
Remaja Putri Tentang Keputihan \\
Fisiologis dan Pathologis di MTS \\
(Madrasah Tsanawiyah) Kota Sema- \\
rang. Jurnal Pengembangan Ilmu \\
Kebidanan 4(1): 48-60. \\
Assefa M, Kumie A (2014). Assessment of \\
factors influencing hygiene behaviour \\
among school children in Mereb Leke \\
District, Northern Ethiopia: a cross- \\
sectional study. BMC Public Health \\
14(1000): 1-8.
\end{tabular}

Attieh E, Maalouf S, Roumieh D, Abdayem P, Abitayeh G, Kesrouani A (2016). Feminine hygiene practices among female patients and nurses in Lebanon. Reproductive Health 13(59): 1-6.

Campbell OM, Benova L, Gon G, Afsana K, Cumming $O$ (2015). Getting the basic rights-the role of water, sanitation and hygiene in maternal and reproductive health: a conceptual framework. Tropical Medicine and International Health 20(3): 252-267.

Chatwani AJ, Hassan S, Rahimi S, Jeronis S, Dandolu V (2006). Douching With Water Works Device for Perceived Vaginal Odor With or Without Complaints of Discharge in Women With No Infectious Cause of Vaginitis: A Pilot Study. Infectious Diseases in Obstetrics and Gynecology: 1-4.

Chillos VD, County R (2006). Knowledge, attitudes, and practices in reproductive and sexual health. McGill Journal of Medicine 9(2): 119-125.

e-ISSN: 2549-1172 (online) 
Crowe S, Cresswell K, Robertson A, Huby G, Avery A, Sheikh A (2011). The Case Study Approach. BMC Medical Research Methodology 11(100): 1-9.

Dasgupta A, Srkar M (2008). Menstrual Hygiene: How Hygienic is the Adolescent Girl? Indian Journal of Community Medicine 33(2): 77-80.

Devi MS, Jaya S (2013). Sexual and Reproductive Health Education for Adolescents: Need of The Hour. Indian Journal of Health and Wellbeing 4(1): 87-90.

Efendi F (2009). Keperawatan Kesehatan Komunitas: Teori dan Praktik dalam Keperawatan. Jakarta: Salemba Medika.

Esber A, Turner AN, Mopiwa G, Norris AH (2016). Intravaginal practices among a cohort of rural Malawian women. Journal of Sexual Health 13: 275280.

Fashemi B, Delaney ML, Onderdonk AB, Fichorova RN (2013). Effects of feminine hygiene products on the vaginal mucosal biome. Microbial Ecology in Health and Dissease 24:1-6.

Garg R, Goyal S, Gupta S (2012). India Moves Towards Menstrual Hygiene: Subsidized Sanitary Napkins for Rural Adolescent Girls-Issues and Challenges. Maternal Child Health Journal 16: 767-774.

Garn JV, Caruso BA, Botsch CD, Kramer MR, Brumback BA, Rheingans RD, Freeman MC (2014). Factors Associated With Pupil Toilet Use in Kenyan Primary Schools. International Journal of Environmental Research and Public Health 11: 9694-9711.

Jasper C, Le TT, Bartram J (2012). Water and Sanitation in Schools: A Systematic Review of the Health and Educational Outcomes. International
Journal of Environmental Research and Public Health 9: 2772-2787.

Keith B (2016). Girls' and women's right to menstrual health: Evidence and opportunities. USA: Path.

Kemenkes RI (2015). Situasi Kesehatan Reproduksi Remaja. Pusat Data dan Informasi Kementrian Kesehatan RI. Jakarta.

Kleinbaum DG, Sullivan KM, Barker ND (2007). A Pocket Guide to Epidemiology. USA: Springer.

Kusmiran E. (2012). Kesehatan Reproduksi Remaja dan Wanita. Jakarta: Salemba Medika.

Kwon JA, Wickrama KAS (2014). Linking Family Economic Pressure and Supportive Parenting to Adolescent Health Behaviors: Two Developmental Pathways Leading to Health Promoting and Health Risk Behaviors. Journal of Youth and Adolescence 43: 1176-1190.

Majerovich JA, Canty A, Miedema B (2010). Chronic vulvar irritation: could toilet paper be the culprit?. Canadian Family Physician 56: 350-352.

Mckee MD, Baquero M, Anderson M, Karasz A (2009). Vaginal Hygiene and Douching: Perspectives of Hispanic Men. Culture Health and Sexuality 11(2): 159-171.

Murti B (2013). Desain dan Ukuran Sampel untuk Penelitian Kuantitatif dan Kualitatif di Bidang Kesehatan. Yogyakarta: Gajah Mada University Press.

(2016). Prinsip dan Metode Riset Epidemiologi. Surakarta: Universitas Sebelas Maret.

Nicole W (2014). A Question for Women's Health Chemicals in Feminine Hygiene Products and Personal Lubricants. Environmental Health Perspectives 122(3): 71-75. 
Ozcelik CC, Aktas E, Celik D, Ocakci AF (2014). Impact of toilet hygiene training program: results from 11- to 16-year-old secondary school Turkish children. International Journal of Public Health 59: 799-807.

Ozyazicioglu N, Unsal A, Sezgin S (2011) The Effects of Toilet and Genital Hygiene Education on High School Student's Behavior. International Journal of Caring Sciences 4(3): 120-125.

Parker AH, Smith JA, Verdemato T, Cooke J, Webster J, Carter RC (2014). Menstrual management: a neglected aspect of hygiene interventions. Disaster Prevention and Management 23(4): 437-454.

Pinem S (2009). Kesehatan Reproduksi dan Kontrasepsi. Jakarta: TIM.

Proverawati A, Misaro S (2009). Menarche Menstruasi Pertama Penuh Makna. Yogyakarta: Nuha Medika.

Shanbhag D, Shilpa R, D'Souza N, Josephine P, Singh J, Goud BR (2012). Perceptions regarding menstruation and Practices during menstrual cycles among high school going adolescent girls in resource limited settings around Bangalore city, Karnataka, India. International Journal of Collaborative Research on Internal Medicine \& Public Health 4(7): 1353-1362.

Singburaudom N (2015). Hydroxychavicol from Piper betel leave is an antifungal activity against plant pathogenic fungi. Journal of Biopesticides 8(2): 82-92.

Sumpter C, Torondel B (2013). A Systematic Review of the Health and Social Effects of Menstrual Hygiene Management. Plos One 8(4): 1-15.
Sulaeman ES (2014). Promosi Kesehatan. Surakarta: UNS Press.

Sulaeman ES, Murti B, Waryana (2015). Aplikasi Model Precede-Proceed Pada Perencanaan Program Pemberdayaan Masyarakat Bidang Kesehatan Berbasis Penilaian Kebutuhan Kesehatan Masyarakat. Jurnal Kedokteran Yarsi 23(3): 149-164.

Thakur H, Aronsson Annette, Bansode S, Lundborg CS, Dalvie S, Faxelid E (2014). Knowledge, practices, and restrictions related to menstruation among young women from low socioeconomic community in Mumbai, India. Public Health Education and Promotion 2(72): 1-7.

Terry, Paul E (2015). What's Past is Prologue: Views from Dr. Lawrence Green. American Journal of Health Promotion.

Tsai AC, Scott JA, Hung KJ, Zhu JQ, Matthews LT, Psaros C, Tomlinson M (2013). Reliability and Validity of Instruments for Assessing Perinatal Depression in African Settings: Systematic Review and Meta-Analysis. Plos One 8(12): 1-12.

Upashe SP, Takelab T, Mekonnen J (2015). Assessment of knowledge and practice of menstrual hygiene among high school girls in Western Ethiopia. BMC Women's Health 15(84): 1-8.

WHO (2016). Global Health Observatory data repository. http://apps.who. Int/gho/data/node.main.REPADO39 ?lang=en diakses tanggal 14 November 2016. 